\title{
DIVINE ACCEPTANCE OF SINNERS: AUGUSTINE'S DOCTRINE OF JUSTIFICATION
}

\author{
DONGSUN CHO*
}

Southwestern Baptist Theological Seminary

\begin{abstract}
I argue that the bishop of Hippo taught sola fide, declarative justification, and the divine acceptance of sinners based on faith alone although he presented these pre-Reformational thoughts with strong emphasis on the necessity of growth in holiness (sanctification). Victorinus and Ambrosiaster already taught a Reformational doctrine of justification prior to Augustine in the fourthcentury Latin Christianity. Therefore, the argument that sola fide and justification as an event did not exist before the sixteenth-century Reformation, and these thoughts were foreign to Augustine is not tenable. For Augustine, justification includes imputed righteousness by Christ's work, which can be appreciated by faith alone and inherent righteousness assisted by the Holy Spirit at the same time of forgiveness in justification. Nonetheless, the sole ground of the divine acceptance does not depend on inherent righteousness, which is real and to increase. The salvation of the confessing thief and the remaining sinfulness of humanity after justification show Augustine that faith alone is the ground of God's acceptance of sinners. Augustine's relatively less frequent discussion of sola fide and declarative justification may be due to his need to reject the antinomian abusers who appealed to the Pauline understanding of justification even when they do not have any intentional commitment to holiness after their confessions. Augustine's teaching on double righteousness shows considerable theological affinity with Bucer and Calvin who are accustomed to speak of justification in terms of double righteousness. Following Augustine, both Bucer and Calvin speak of the inseparability and simultaneity of justification and sanctification. Like Augustine, Bucer also maintains a conceptual, not categorical, distinction between the two graces of God in their doctrines of justification.
\end{abstract}

KEY WORDS: Sola Fide, Good Works, Double Righteousness, Merit, Martin Bucer

\section{Introduction}

Since Augustine in the Reformational theologies of Luther and Calvin was the most important authority next to the Bible concerning the grace of God, many Protestant readers might assume that Augustine would be a certain forerunner of the Reformational understandings of justification: declarative and instantaneous justification, sola fide, imputed righteousness, and a meaningful distinction between justification and sanctification. However, reading the works of some Lutheran (Saarnivaara, 1951; Hägglund, 1966) and other Protestant (Heckel, 2004;

* DONGSUN CHO (PhD 2008, Southwestern Baptist Theological Seminary) is Assistant Professor of Systematic and Historical Theology at Southwestern Baptist Theological Seminary in Fort Worth, Texas, United States of America. Email: dcho@swbts.edu 
McGrath, 2005) scholars would radically challenge one's Protestant presuppositions of Augustine. These Protestant scholars deny any essential theological continuity between Augustine and the Reformers with regard to justification. They deem Augustine as the Patristic founder of the Roman Catholic doctrine of justification: the inherent, not imputed, righteousness of justification by the infused grace and good works, not faith alone, as a contributing cause to God's ultimate justification of sinners. In addition, Catholics such as O'Collins and Rafferty (2011: 269) and Protestants such as McGrath (2005: 31, 38) contend that there was no significant patristic tradition concerning justification by faith prior to Augustine. In this theological perspective, it is anachronistic to attempt to find a theological precursor of the Reformational doctrine of justification in the early church either before or in Augustine.

However, this paper argues that Augustine has more theological affinity with the Reformation movement than with the Catholic Church in the doctrine of justification. As a matter of fact, Augustine's doctrine of justification finds strong theological defense from Martin Bucer rather than later Luther and Melanchthon who made an explicit categorical distinction, not separation, between justification and sanctification. In contrast to the two Lutheran Reformers, Bucer did not see any theological conflict between the bishop's teaching of imputed and inherent righteousness and of eternal life as a reward for good works and his own Reformational view of sola fide and imputed righteousness. In order to attest the thesis of this paper, we need not only a careful reading of Augustine but also a critical historiography of the doctrinal development concerning justification. The evidence of a patristic tradition teaching sola fide before Augustine in the Latin tradition would help us avoid our biased presupposition that sola fide was not known to Augustine. Augustine's key texts on justification will be examined and compared with some Reformers' views, especially with Bucer's. Bucer may be the Protestant Reformer whose doctrine of justification is very much similar to Augustine's in many ways. If Bucer's understanding of double (imputed and inherent) righteousness could be considered as a legitimate form of the Reformational doctrine of justification, we could also conclude that Augustine can be considered a patristic forerunner of the Reformational understanding of justification in some real sense although he cannot be a sixteenth century Reformer in every aspect.

\section{A Latin Patristic Tradition of Justification by Faith Alone before Augustine}

Gaius Marius Victorinus (300-?), an African Roman, might be the first Latin Pauline exegete who taught justification by faith alone. ${ }^{1}$ We could easily find his explic-

1

In contrast to Eno (1984) and Williams (2006) who deny any meaningful presentation of the Reformational view of justification in early Christianity, in particular, this paper presents Victorinus and Ambrosiaster as the Latin exegetes, prior to Augustine, who held to sola fide. With regard to Victorinus, Cooper (2005) presents substantial evidence of justification by sola 
it references to sola fide in his commentary on Galatians that is full of expressions such as 'non secundum operas iustificemur, sed secundum fidem' or 'non ex operibus legis iustificemur, sed ex fide et fide in Christum'. In his exegesis of Philippians 3:9 Victorinus asserts, 'the righteousness of God' is 'not the righteousness which is by the law and which is in works and by the discipline of flesh but the righteousness which proceeds from God', that is, 'righteousness by faith, faith in Christ' (Victorinus, 1986: 206). Philippians 2:13 clarifies that the righteousness of justification is not ours but God's alone although we need to work out our salvation. For it is God, not us, that makes us desire and work for the accomplishment of God's will (Victorinus, 1986: 195). The righteousness of justification has been counted or imputed [reputatum] to believers, and, for believers, even the entire Christian life will be counted or imputed [reputabitur] as righteous (Victorinus, 1986: 129). Ephesians 2:9 rejects that the Christian's 'merit based on a moral obligation [for the poor]' and his 'merit based on religious observation of chastity and abstinence' constitute justification (Victorinus, 1986: 33). Victorinus (1986: 130) views 'faith plus works' theology as nothing but 'justification by works'. Interestingly, this Pauline exegete argues in his comments on Galatians 2:15-16 that not only justification but also sanctification are by 'sola fide' (Victorinus, 1986: 122). In his comment on Galatians 6:14, furthermore, Victorinus emphasizes the importance of personal holiness subsequent to faith. Without subsuming justification under sanctification, the ancient commentator maintains the inseparable union between the two graces of God. Paul urges his Christian readers to put on 'the breastplate of righteousness after faith' as 'personal righteousness' or 'the righteousness of the 'works of Christian religion [opera christianitatis]' to be 'commanded by apostles to be fulfilled by every Christian [opera ab apostolo omni Christiano inplenda mandatur]' (Victorinus, 1986: 130). Based on Bakhuizen van den Brink's work on the Latin term mereri, Cooper concludes that Victorinus preserves a distinction between the verb mereri in a 'sensus laxior [to obtain]' and a 'sensus strictior [to obtain deservedly]' and consistently rejects merit in a sensus strictior in relation to justification and salvation (Cooper, 2005: 162).

Ambrosiaster (d. late fourth century) continuously presents the exegetical defense of sola fide in Latin Christianity. His commentary on Romans provides us enough materials to see his appeal to sola fide. According to Ambrosiaster (1966: 118), Paul teaches that Christians are 'justified freely, neither because they have labored nor because they have made a repayment, but by faith alone they are jus-

fide in Victorinus' commentary on Galatians (see Cooper, 2005: 182-246). With regard to Ambrosiaster's doctrine of sola fide, see the sixteenth century Lutheran Chemnitz (1989) and Bray (2005). Bray also attests Ambrosiaster's teaching of sola fide through the Latin exegete's Pauline commentaries. For further systematic analyses of both Victorinus' and Ambrosiaster's Reformational understandings of justification, see Cho (2012; 2014).

PERICHORESIS 12.2 (2014) 
tified by the gift of God', 'faith alone is laid for salvation', and 'God would set only faith by which all sins may be abolished'.

Due to the bondage of the will and inherited sins, we cannot completely satisfy the absolute righteousness of the law. Therefore, we received faith by which we could believe in Christ who himself is 'the perfection of the law' by 'making a satisfaction of the total law for everyone who transgresses' (Ambrosiaster, 1966: 344). Ambrosiaster also presents justification as a legal issue in two ways. First, justification frees believers from their legal duty to pay their debts in full to God since Christ 'destroyed the certificate of debt which had been decreed by the sin of Adam' (Ambrosiaster, 1966: 215). Second, justification also frees them from the punishment of 'hell' when they believe in Christ (Ambrosiaster, 1969: 3.170). The purpose of purification from sins and liberation from penalties by justification is for us to 'offer a living sacrifice so that it may a proof of eternal life' (Ambrosiaster, 1966: 395). In his comments on Romans 3-9, Ambrosiaster (2005: 32-33) already presents the assurance of salvation based on declarative righteousness and the non-imputation of sins.

His [a believing Gentile's] faith is reckoned for righteousness as Abraham's was... Obviously they are blessed, whose iniquities are forgiven, without labor or work of any kind, and whose sins are covered without any work of penitence being required of them, as long as they believe. Forgive, cover, not reckon - it all amounts to one and same thing... what he has covered he has forgiven, and what he has forgiven he does not reckon [to the sinner]... so that this blessed many have perfect assurance and glory.

Ambrosiaster also teaches the imputed righteousness of Christ for our justification. First, for the ancient exegete Christ himself is 'the righteousness from God' that justifies us (Ambrosiaster, 2005: 9). Second, we enjoy all of the legal benefits, including forgiveness, and justification through our union with Christ (Ambrosiaster, 1969: 7). Third, the righteousness of justification is presented as a passive form of the verb impute [to impute]. Righteousness was given to Abraham and his spiritual descendants not 'by the works of the law but by faith' (Ambrosiaster, 1969: 32, 40). Ambrosiaster presented more theological ground for imputed righteousness in light of our union with Christ than Victorinus does.

The above historiographical review of a Latin patristic tradition of sola fide prior to Augustine has several historical and theological implications for our study of Augustine on justification. First, the term 'sola fide' and its idea already appeared in the fourth century Latin Pauline commentaries. Second, justification was a central theme to the commentaries. Third, the righteousness of justification is not ours but God's and, therefore, imputed to us by faith alone. Fourth, neither Victorinus nor Ambrosiaster had a categorical distinction between justification and sanctification as distinct theological subjects. However, they demonstrated a conceptual distinction between the two. Without conflating justification with sanctification, the Latin commentators simultaneously pinpointed the indissoluble rela- 
tionship between the two graces of God and consistently asked sanctification as evidence of justification.

The issue of the exact nature of Victorinus and Ambrosiaster's influence on Augustine has been debated among scholars. Nonetheless, there are considerable works that show Augustine was influenced by the two Pauline exegetes in his theology. Recent research shows that Victorinus' exegetical and theological influence can be seen both in Ambrosiaster and Augustine (see Cooper, 2005: 182-246). However, this paper does not argue that Augustine's doctrine of justification is essentially identical with either Victorinus' or Amborsiaster's doctrine of justification. Rather, this paper argues that Augustine's presentation of justification takes a different course, while not denying the tradition of sola fide in Victorinus and Ambrosiaster.

\section{Augustine's Definition of Justification as Double Rigtheousness}

Like Victorinus and Ambrosiaster, Augustine identifies justification with the forgiveness of sins in various places. In Punishment and the Forgiveness of Sins 1.12.16, Augustine (1997: 42) explains the nature of justification in terms of forgiveness of all sins-original sin and personal sins. Justification as the forgiveness of sins is based on Christ's redemptive work. In the same work 2.20.34, Augustine (1997: 102) presents atonement and justification as one pair of God's grace: 'In him [Christ, the one mediator between God and man] is found our atonement and justification, by which the hostilities resulting from sin have been ended and we have been reconciled to God'. Unlike Victorinus and Ambrosiaster, however, Augustine (1997: 178-179) sees the renewal of human nature as another qualification for justification: 'What else, after all, does justified (Romans 3:24) mean but: made righteous by the one, of course, who justifies sinners (Romans 4:5), so that from sinners they become righteous?' To become righteous or to be justified is 'by the gift of God through the assistance of the Holy Spirit... God bestows this righteousness [of God with which he cloths a human being when he justifies a sinner] upon the believer through the Spirit of grace without the help of the law' (Augustine, 1997:158). The forgiveness of sins through faith and the renewal of life through the Holy Spirit are inseparable and simultaneous blessings in the one divine act of justification. The forgiveness of sins in Augustine does not end with liberation from guilt and punishment, but entails a 'fundamental' change within humanity, and produces a 'new concrete righteousness' that creates the real improvement of human nature (Rydstrøm-Poulsen, 2002: 42-43). For Augustine, therefore, the righteousness of justification is twofold: righteousness from Christ's redemptive work of the forgiveness of sins and righteousness from the new nature changed by the Holy Spirit. Augustine's Sermon 158.4-5 explains well how the two graces of God are related to the Christian life:

'I am just' amounts to the same thing as 'I am not a sinner'... I mean, here we are with people who have been baptized, all their sins have been forgiven, they have been justi- 
fied from their sins. We can't deny it... So this third thing [justification in Romans 8:30] is already happening in us. We have been justified; but this justice can grow, as we make progress. And how it can grow I will tell you, and after a fashion compare notes with you, so that you may all, each and every one of you, already established in the condition of justification, namely by receiving the forgiveness of sins in the washing of regeneration, by receiving the Holy Spirit, by making progress day by day (1992: 116-117).

The first righteousness of justification as the divine forgiveness is an undeniable and present reality to all Christians regardless of the different degrees of their perfection. The second righteousness of justification as the justice of the justified, who still struggle with the flesh, and must grow through our cooperation with the Holy Spirit in our daily lives. Therefore, McGrath (2005: 47-48) claims that for Augustine justification is an 'event' 'by operative grace' and a 'process' by 'cooperative grace', and inherent, rather than imputed, righteousness is what God grants to believers in justification. McGrath (2005: 49) continues to argue that the bishop, in contrast to the Reformers, 'effectively subsumed' sanctification under the umbrella of justification. McGrath does not see Augustine as a forerunner of the Reformational doctrine of justification in any sense.

Nonetheless, we should not quickly judge Augustine's double righteousness as the indicator of no theological continuity between him and the Reformers. The inclusion of the renewal of the image of God in the doctrine of justification is also found among some Reformers. Not all Reformers restricted justification to a forensic matter. There was a conceptual flux of a Protestant definition of justification before the era of Protestant confessionalism among the Protestant Reformers (Lugioyo, 2010: 144). Even early Luther did not make an explicit distinction between justification and sanctification. As a matter of fact, he 'considered justification both an event and a process' (Woodbridge and James, 2013: 110). ${ }^{2}$ Luther's emphasis on the forensic aspect of justification and a theological distinction between justification and sanctification appeared in his later works such as Apologia (1530) and Commentary on Galatians (1535). Toon (1983: 62-63) notes that Melanchthon influenced Luther in the latter's development of a legal aspect of justification. For Calvin, sanctification is also not 'the consequence of justification', but the former is 'simultaneously accompanying' the latter 'through the same faith' (Raith, 2001: 26). It is rather Bucer that speaks of both forgiveness and inner renewal as the immediate effect of forgiveness in the most explicit way. The forensic righteousness based on the divine pronouncement of forgiveness simultaneously 'effects a psychological and anthropological change that cannot be separate from the justification process' (Lugioyo, 2010: 60). Like Augustine, Bucer also present-

2 According to Bromiley (1952: 95), Luther used the term 'justification' in order to 'cover the process of sanctification as well as justification in the narrower and stricter sense'. Like Augustine, Luther used even the metaphor of healing in his explanations of the nature of justification (Woodbridge and James III, 2009: 110).

PERICHORESIS 12.2 (2014) 
ed that the justifying faith inevitably and immediately entails the work of the Holy Spirit transforming the fallen humanity still under the power of concupiscence. Even Bucer argued that it was Paul who talked about justification in terms of forgiveness and renewal at the same time (Stephens, 1970: 52). Both Augustine and Bucer affirm that the believer receives both faith and the Holy Spirit at the same time when he converts. Without the ministry of the Holy Spirit, no one can understand and believe the promise of God for salvation.

Like Augustine, Reformers such as Bucer and Calvin could also speak of 'double righteousness' or 'double justification'. Bucer conceived the first justification as 'the justification of the ungodly (as in Paul)', and the second as 'the justification of the godly (as in James)' (Stephens, 1970: 53). Like Augustine, the Reformer also claims that this double righteousness is the way Paul explains justification (Stephens, 1970: 52). Here we need to notice that Bucer's usage of double justification is different from Girolamo Seripando's usage. At the Council of Trent, Seripando presented double justification and inherent righteousness, in addition to imputed righteousness, as the second formal cause of the divine acceptance of sinners (Lugioyo, 2010: 43). Bucer never accepted inherent righteousness as the second formal cause of justification although he admitted the necessity of immediate inherent righteousness within the justified humanity by the ministry of the Holy Spirit at the moment of justification. In Bucer's theology, however, double justification is always based on the single cause of the imputed righteousness of Christ (Beeke and Jones, 2012: 802; Stephens, 1970: 55). ${ }^{3}$ For Bucer imputed righteousness is 'a stimulus' rather than 'a supplement' to inherent righteousness (Lugioyo, 2010: 102, 132). In his Institutes 3.17.4, Calvin (1960: 806) also used the phrase 'a double acceptance before God' and was ready to accept the concept of 'double righteousness' presented by the Regensburg colloquy (1541), which captures Bucer's doctrine of justification (Venema, 2007: 163). It is Bucer, however, that explicitly continued Augustine's legacy of the double righteousness of justification and explained why Protestants should not be embarrassed with Augustine's double justification (Lugioyo, 2010: 43-46).

In evaluating whether Augustine's view of justification could be the theological antecedent of the Reformational understanding of justification, the more important question is not to be whether he made a categorical distinction between justification and sanctification in his doctrine of justification. As we observed above, not only Augustine but also early Luther and Bucer did not talk about justification in a purely forensic way. Bucer never hesitated to speak of double right-

Lane does not see Bucer as a responsible theologian who formulated the twofold righteousness of justification based on sola fide, not caritate. Rather, Lane views this double righteousness concept as a unique contribution of the Regensburg colloquy to Christian theology (Lane, 2004: 217). However, Lugioyo (2010: 12, 163) presented Bucer as the responsible theologian for the double righteousness of Regensburg. 
eousness in his discussion of justification. Even Calvin demonstrated his willingness to explain justification in terms of double righteousness with emphasis on imputed righteousness as the singular ground of the divine acceptance of the sinners. It is possible for Augustine to have a conceptual, if not categorical, distinction between justification and sanctification, or personal righteousness to grow by the assistance of the Holy Spirit. Other questions may be necessary in determining whether Augustine indeed holds a conceptual distinction between justification and sanctification, while maintaining the context of the inseparable and simultaneous relationship between the two graces of God. Acknowledging that Augustine used the term 'justification' as a reference to both the change of 'state' and that of 'character' of sinners by the grace of God, Buchanan (1867: 91) also contended in a similar spirit, 'there is no evidence to prove, either that he [Augustine] confounded these two blessings [justification and sanctification] of God's grace, or that he made the one the ground or reason of the other'. Therefore, we should ask the following questions. First, is the divine acceptance of sinners for Augustine contingent upon inherent righteousness assisted by the Holy Spirit? Or is such divine acceptance already fixed based on the divine forgiveness through declared justification? We will examine whether Augustine teaches imputed righteousness. Second, what might be the relationship between imputed righteousness by faith and inherent righteousness by the cooperation between the Holy Spirit and our free will? We will examine whether good works are supplement to or a witness to faith. Third, how should we understand Augustine's emphasis on eternal life as a reward for good works? We will examine how his teaching of a reward for eternal life is to be understood in his central theology of grace.

\section{The Ground of the Divine Acceptance of the Sinners in Augustine's Doctrine of Justification}

No one would oppose that Augustine presented the forgiveness of sins as inevitable to God's ultimate acceptance of sinners. The issue is whether the bishop saw the forgiveness of sins as the sole ground of God's eschatological acceptance and as a fixed and present blessing to all Christians. If the forgiveness of sins is contingent upon the increase of inherent righteousness, however, Augustine's understanding of justification will be fundamentally Catholic, not Reformational. In pursuing a proper answer to the above research question, we need to recognize how Augustine uses the perfect passive verb form iustificatus [have been justified] and iustitia [justice] or iusti [just]. As he already demonstrated in Sermon 158.4-5, he uses iustificatus when he needs to address legal righteousness through forgiveness, and every Christian possesses that righteousness in their present reality. ${ }^{4}$ On the other hand, he uses iustitia when he refers to personal righteousness to be 1.2.3; De spiritu et littera $10.16,29.51$.

PERICHORESIS 12.2 (2014) 
increased by the help of the Holy Spirit from the moment of regeneration to the end of a Christian's spiritual journey. His unique usage of iustificatus for the completion of justification is also found in Tractates on the Gospel of John 3.12. Here Augustine (2009: 77) contrasts being in Adam with being in Christ. The result of being in Adam makes all human beings sinners. Likewise, the result of being in Christ means that all Christians 'have been justified and just, not in themselves but in him (Christ) [omnes qui per Christum, iustificati et iusti non in se, sed in illo]' (Augustine, 1841: 1401). In his Exposition of Psalm 150.3, Augustine (2004: 512) paid attention to the fact that the spiritual sequence of calling, justification, and glorification refers to the completion of justification in the Christian life. One's calling, justification, and glorification consist of a theological parallel to that of Christ's cross, burial, and resurrection and to that of our repentance, justification, and eternal life (Augustine, 2004a: 512). Exposition 2 of Psalm 88.4 points to all the three spiritual gifts which are promised in the 'unshakeable' covenant of God based on his predestination (Augustine, 2002: 292). As we, genuine believers, have been already predestined and called, so we have been already justified (Wright, 2006: 71). For Augustine not only legal righteousness but also personal righteousness per se through forgiveness in the process of justification could be considered as the immediate effects of the one divine event of justification rather than a long process of sanctification. Therefore, Hiestand is right when he argues, 'For my part, I do not see progressive justification in Augustine. While it is certainly true that he speaks of growth in righteousness, his actual use of iustificare [to justify] seems semantically limited to initial regeneration and conversion' (2007: 130, n. 53).

I would argue that for Augustine the ground of the divine acceptance of sinners is the divine forgiveness, not the immediate personal / inherent righteousness [iustitia] that Christians simultaneously receive with the divine forgiveness by justification in the moment of regeneration. Unlike McGrath and Wright, I would not consider that the progressive righteousness and cooperative grace after initial regeneration is another cause, besides the divine forgiveness and the immediate inherent righteousness by justification, of the divine acceptance of sinners. McGrath (2005: 47-49) agrees with Catholics that Augustine requires human merits in the process of justification by co-operative grace. However, Rydstrøm-Poulsen (2002: 39-40) points out that it is wrong to view operative grace as a theological referent to a monergistic work of God in the forgiveness of sins and cooperative grace as a theological referent to 'a synergistic relation between God and man' in the completion of justification, since the nature of the Augustinian grace as an 'absolute gift and praeveniens [preceding] — and man as solely receiving-is not changed' in spite of the description of cooperative grace. For Augustine cooperative grace is 'no secondary and supplementing grace', but it is the same as operative grace that turns sinners 'into good trees that bear good fruit' (Rydstrøm-Poulsen, 2002: 59). In his Exposition of 1 of Psalm 34.14, Augustine speaks of the believing thief who died with the Lord, and yet was saved. What the thief had was just his faith in and 
confession about Jesus Christ. Nonetheless, the Lord promised to bestow eternal life upon the thief because he was already 'made righteous [iustificatus]' in spite of his robbery (Augustine: 1956: 310). His righteousness that saved him was simply based on his faith and confession on the cross. If the thief was not truly justified for eternal life, 'the Lord could not have promise to one who was still unrighteous and not yet justified' (Augustine, 2000:56). Similarly, in Miscellany of Eighty-Three Questions 76.1, Augustine is very emphatic about the sufficiency of genuine faith as the sole ground of the divine acceptance of sinners:

If soon after having believed he departs from this life, the righteousness of faith remains with him-neither on account of antecedent good works, because he attained to it not by merit but by grace, nor on account of subsequent ones, because none were permitted him in this life (2008: 140-141).

Augustine highlights the necessity of good works that must come from justifying faith right before and after the immediate context of the above text. The bishop unmistakably teaches not only the necessity of good works subsequent to faith but also the demonic nature of the faith that does not produce them. Nevertheless, his intention to require the increase of personal righteousness through good works subsequent to faith was not to deny the sufficiency of righteousness by genuine faith in conversion or regeneration as the cause of salvation but to prevent the abusers of the sola fide theology from excusing their sins.

Does Augustine's doctrine of justification have declarative and imputed righteousness? McGrath (2005: 47, 48) contends that 'inherent, rather than imputed' righteousness is essential to Augustine and declarative or imputed righteousness is 'redundant' at best in his doctrine of justification. In contrast to McGrath, Wright (2006: 70, 71) senses that Augustine 'teaches something close to a declarative justification by faith, perhaps even faith alone', but even the Reformed theologian concludes that the ancient bishop 'does not help his interpreters as much as he might to understand how event and process are correlated in his thinking'. Wright thinks we could find Augustine's declarative teaching of justification from Romans 2:13- 'the doers of the law will be justified'. Unfortunately, Augustine's reference to the declarative teaching in this passage seems accidental to Wright who claims that he does not see other references to the declarative righteousness of justification. Let us carefully review the text of The Spirit and Letter 26.45 (1997: 178-179):

We realize that they fulfilled the law only because they are justified. Thus justification does not follow upon the observation of the law; rather, justification precedes the observation of the law. What else, after all, does justified (Romans 3:24) mean but: made righteous by the one, of course, who justifies sinners (Romans 4:5), so that from sinners they become righteous? After all, if we were to say, 'Human beings will be created', one would certainly not understand that those who already [iam] were human beings are created, but that they became human beings by being created. So too, if it were said,

PERICHORESIS $12.2(2014)$ 
'Those who observe the law will be honored', we would correctly interpret it only in the sense that honor is given to those who were already observing the law... Accordingly, it ['the doers of the law will be justified'] is the same as if one were to say, 'Those who observe the law will be created', not because they [who observe the law] already existed, but so that they might exist... it is certainly true that they will be justified in the sense that they will be considered as righteous [iusti habebuntur], that they will be counted as righteous [iusti deputabuntur]. In that sense scripture says of a certain man, But he wanting to justify himself (Luke 10:29), that is, wanting to be considered [haberetur] and counted [deputaretur] as righteous. ${ }^{5}$

From the above quotation, we could extract some theological lessons on justification. First, justification is already actualized before the completion of inherent righteousness. Inherent righteousness is the result of this declarative or imputed righteousness. If Paul wanted to teach the dependence of justification upon inner righteousness from post-conversion merits, he could have said, 'the doers of the law will be honored' because 'the honor is given to those who were already observing the law', and honor, unlike being justified, is a due payment to those who have been observing the law. Second, the righteousness of justification is definitely declarative. Does Augustine suggest here that God at the last judgment will declare believers as being justified because inherent righteousness assisted by the Holy Spirit will be actually good and righteous enough of earning eternal life? Those who will be honored by observing the law have inherent righteousness, but being made justified is God's work like his creation in that justification and creation themselves do not have inherent righteousness to merit God's grace. Justification is God's considering or regarding believers to be made righteous.

In fact, there are more texts that advocate the Augustinian understanding of the declarative or imputed righteousness of justification. In Punishment and the Forgiveness of Sin 1.14.18 [1997: 43], Augustine (PL 44: 119) reminds his readers of no inherent power of justification in human beings and of the necessity of imputed righteousness through Christ: 'He says, Believe in God and believe in me (John 14:1); so that, because he makes the sinner righteous, the faith of one who believes in him may be counted as righteousness [deputetur fides ad iustitiam]'. In Revisions 2.33, Augustine sums up what he taught in Punishment and the Forgiveness of Sin. With regard to justification, he (1997: 140) points to the declarative nature of justification once more: '[By the grace of God] we are justified (that is, rendered just), although there is no one in this life who so observes the commandments of justice that, because of his sins, he does not need to say in prayer, Forgive us our debts (Matthew 6:12).' The other illustration for imputed justification is that of clothing. In Grace and Free Choice 6.13, Augustine (1865: 889-890) points to a distinction between justifying and sanctifying grace: 
For that reason, man needs not only the grace of God to justify the wicked man [gratia Dei non solum iustificetur impius], that is, to make him righteous from wickedness, when good things are rendered to him for evil ones. But once a human being has been already justified by faith [cum fuerit iam iustificatus ex fide], he needs grace to walk with him so that he may lean on it in order not to fall [ambulet cum illo gratia, et incumbat super ipsam ne cadat]. On this account the Song of Songs says of the Church, Who is this who arises dressed in white, leaning upon her beloved? (Song of Songs 8:5)... who has dressed her in white but he who says through the prophet, If your sins are like scarlet, I shall make them white as snow (Isaiah 1:18)?... but now, having been already dressed in white [iam vero alba facta], she lives a good life.

Augustine's illustration of clothing is also used in The Spirit and the Letter 9.15 (1865: 209): 'With the righteousness of God, God clothes a human being when he justifies a sinner [qua induit hominem, cum iustificat impium].' The justifying righteousness is ours not because it is inherent in us, but because God puts it on us, and, therefore, we have a real, not imagined, righteousness. In order to preserve the divine origin without any human contribution, Augustine (1997: 158) does not forget to say, 'but they are said to be God's and Christ's, because they are given to us by God's generosity'. Augustine's phrase 'ours' merely indicates that believers now have a real righteousness that has justified them who are still sinful, without arguing that their inherent righteousness increased by the power of the Holy Spirit is the ground of justification. After emphasizing the punctiliar aspect of justification, the bishop compares justifying grace to the white dress that God puts on believers when forgiving all their sins. Being already dressed in white is justification, and living a holy life subsequent to being dressed with righteousness is sanctification. Here Augustine uses this clothing illustration as an indication of the imputed righteousness of God, a point that McGrath unequivocally denies as Augustinian. Augustine's emphasis on the necessity of growth in inherent righteousness subsequent to faith does not necessarily mean that imputed righteousness by faith in Christ is not sufficient for our salvation. Bucer also teaches the simultaneous occurrence of imputed righteousness and inherent righteousness when Christians experience regeneration. God makes the sinner righteous by granting him imputed righteousness:

We are justified by faith, that is, we receive a justification that is freely given, by virtue of which the heavenly Father considers us just, and we receive a kingdom through Christ his Son. We are justified by deeds and words, that is, we are declared and judged just, both in our own eyes and in those of the rest of mankind, who are able to judge from [our] fruits (Stephens, 1970: 50, n. 3).

However, inherent righteousness assisted by the Holy Spirit does not make him righteous 'in a way that he does not always stand in need of the unmerited forgiveness of God' (Stephens, 1970: 49). Not only Bucer but also the ecumenical colloquy of Regensburg presents the Augustinian priority of imputed righteousness 
as the sole condition of justification without giving up emphasis on the necessity of inherent righteousness in the Christian life. In spite of suspicion from other Protestants such as Luther and Melanchthon concerning the phrase 'efficax per caritatem (effectual through love)' in article 5 of Regensburg on justification, the authors of that article carefully excluded the Catholic notion of the divine acceptance of sinners based on imparted righteousness or justification by love. The authors defended sola fide by qualifying the phrase with a statement, 'So living faith is that which both appropriates mercy in Christ, believing that the righteousness that is in Christ is freely imputed to it' (Lane, 2006: 144). What Regensburg attempted to achieve was to teach imputed righteousness as the formal cause of justification, which must be appropriated by faith alone without denying the simultaneity of imputation and impartation of righteousness in justification. After pointing to the simultaneity of faith and love working in justification, the article once again wanted to preserve sola fide without compromise:

Nevertheless, it remains true that it is by this faith that we are justified (i.e., accepted and reconciled to God) inasmuch as it appropriates the mercy and righteousness that is imputed to us on account of Christ and his merit, not on account of the worthiness or perfection of the righteousness imparted to us in Christ (Lane, 2006: 144).

Despite the Lutherans' and Catholics' rejection of the Regensburg doctrine of justification, Bucer and Regensburg truly stand in the spirit of Augustine in presenting imputed righteousness as the sole ground of divine acceptance of sinners and at the same time in honoring the inseparability and simultaneity of imputed and inherent righteousness in justification. I do not see any explicit textual evidence that Augustine presents inherent righteousness as another cause in order to supply what imputed righteousness alone does not provide for the divine acceptance of sinners at the final judgment.

\section{The Relationship between Faith and Good Works in Augustine's Doctrine of Justification}

Alister McGrath (2005: 46) states that 'it is unacceptable to summarize Augustine's doctrine of justification as sola fide iustificamur - if any such summary is acceptable, it is sola caritate iustificamur'. Without any doubt, the North African theologian often uses the phrase 'faith working through love' (Galatians 5:6) in explaining the nature of justification. ${ }^{6}$ McGrath (2005: 46) claims that Augustine's 'strong intellectual element' in his concept of faith necessarily demands the supplement of love in justification misrepresents Augustine's efforts to prevent any misapplication of sola fide. Disagreeing with McGrath's conclusion that faith in the 
theology of Augustine is merely intellectual and necessarily requires caritas as its supplementation, Wright (2006: 67) attests, following Burnaby and Gilson, that faith for Augustine is both intellectual assent to the truth of God and personal trust in the loving God. Then, why does Augustine so underscore the necessity of good works related to justification in a way that many would misinterpreted him? In the last decades of his life, Augustine had many readers who abused the Pauline doctrine of sola fide and declarative justification. Therefore, Augustine has to appeal to the apostle James who condemns the concept of sola fide without good works as a false assurance and a demonic faith. At first glance, Augustine seems to deny sola fide. However, the context must determine what he means with his statement, 'faith alone is not sufficient for salvation'. In Reconsiderations 2.38, Augustine recalled that he already had to deal with an antinomian definition of faith in his another work Faith and Works as a mental assent to the message of the gospel without personal and existential commitment to Christ as the Lord. Faith and Works was to show how regenerate Christians ought to live and how the church should judge the qualifications of candidates for baptism. Therefore, Augustine's target audience is not those who want to know how to be born in Christ, but rather those who confess their Christian faith with their mouths but do not have holiness in them. In Faith and Works 14.21 (1887: 211), Augustine warns against a group that promotes 'the false assurance of salvation [mala securitate salute]' by saying that evil things do not matter to their salvation, but faith alone matters as Paul teaches, 'Where sin abounded, grace more abounded' (Romans $5: 20)$. Some Christians argued they could do whatever they wanted to do because their faith was 'reckoned to' them 'as righteousness' (Augustine, 2000a: 364). In response to this antinomian group, Augustine (1975: 265) says that 'faith is not sufficient' for salvation, and faith alone without holiness refers to 'the faith not of Christians but of demons [fidem not christianorum sed daemonuum]'. The abuse of declarative righteousness based on sola fide without commitment to love and holiness might be a reason why Augustine did not frequently speak of the declarative, imputed and instantaneous elements of justification. Consequently, we should not take Augustine's argument-sola fide is not sufficient for salvation-as his theological endorsement of justification by sola caritate.

In his controversy with Pelagians, Augustine needed to refute both the forgiveness of sins based on the fulfillment of the law but also their complete confidence in the post-conversion human will to accomplish the requirements of the law without the grace of God (Riches, 2008: 117). Therefore, Augustine's goal is not only to explore the uselessness of good works prior to the grace of forgiveness but also to prove the same gratuitousness of grace during the period of the renewal of Christian life. Some Reformers complained about the manner of Augustine's presentation of a meaningful relationship between grace for forgiveness and grace for progressive renewal. For Chemnitz (1989: 522b), 'Augustine and the others did not distinguish accurately enough those passages of Scripture where 
the word grace refers to free acceptance by God and those passages in which the word means 'gifts' [of sanctification].' In Institutes 3.11.15, Calvin was also disappointed with Augustine's 'manner of stating' justification, a manner according to which Augustine 'subsumes grace under sanctification by which we are reborn in newness of life through the Spirit' (Calvin, 1960: 746).

Despite those Reformers' complaints about Augustine, Augustine maintains a notable distinction between the role of faith and the role of good works in justification. While emphasizing the inevitability of good works for the justified, however, Augustine (2008: 47) often clarifies the theological order between faith and good works. Good works do not create grace but are made by grace and, therefore, they must be a result of grace. Luther and Calvin would not attempt to correct any part of Augustine's above responses to antinomians because the Reformers also condemned antinomianism and had a clear emphasis on the necessity of good works as evidence of genuine faith. As a matter of fact, Calvin, states, 'It is not our doctrine that the faith which justifies is alone; we maintain that it is invariably accompanied by good works; we only contend that faith alone is sufficient for justification' (2005: 152). Likewise, for Augustine, faith is the only ground of justification, while good works are the necessary evidence of the genuineness of faith:

The two apostles [Paul and James] are not contradicting each other... he [Abraham] offered his son to God as a sacrifice. That is a great work, but it proceeded from faith. I have nothing but praise for the superstructure of action, but I see the foundation of faith; I admire the good work as a fruit, but I recognize that it springs from the root of faith (2000a: 364-65). What righteousness is this? The righteousness of faith, preceded by no good works, but with good works as its consequence (2000a: 370).

While Augustine is so concerned about an antinomian abuse of Paul's sola fide, he does not want his audience to lose a meaningful distinction between faith and good works in justification. There should be no separation between the fruit and root or superstructure and foundation, but neither are they the same entities. Since good works are not the ground of faith, they cannot be the ground of justification that takes place by faith alone apart from good works. Explanation of the Psalms [392].31.2.3 presents that the absence of fruit simply shows that the root has been 'dead [mortua]', 'barren [sterilis]', and 'parched [arida]' (1956: 38.226-27). What Augustine does is to qualify the sola fide principle in justification from a possible misreading of faith alone by antinomians.

Bucer may provide a more accurate interpretation of Augustine on the relationship between faith and good works than any other Reformer. Bucer (Lugioyo, 2010: 52) reads Augustine's emphasis on the inward change of humanity in the 'effective sense' of justification. The Reformer does not find any reason to disagree with Augustine in that justification is related to the impartation of righteousness [sanctification], which God proceeds to work in us by the Holy Spirit. However, inner righteousness is not causative of justification. For Bucer, Augustine presents 
inner righteousness as the natural result of justification. Therefore, Bucer (Lugioyo, 2010: 197) advises his Protestant audience not to be embarrassed when hearing Augustine's definition of faith as faith working through love because the bishop simply defines faith 'in terms of effect'. Bucer (Lugioyo, 2010: 197) goes on to qualify further what Augustine meant by 'faith working through love':

He [Augustine] meant to reveal faith by reference to that mark through which its integrity is more easily recognizable. Not for a moment did he hold the opinion that our salvation is based upon the merit of this love or any other kind of merit except Christ's alone, as every page of his works bears lucid testimony. But since true faith in Christ never fails to produce its proper fruit, he considered that what is not so obvious, the essence and character of true faith, should be exhibited, following the apostle's practice, from the more visible reality of love.

\section{Eternal Life as a Reward for Good Works in Augustine's Doctrine of Justification}

To contemporary Protestants' surprise, Augustine really defines eternal life as a reward for our merits although he qualifies this with his strong emphasis on the divine initiative and gratuitous nature of eternal life as a reward. To live righteously is a divine commandment, and eternal life as our reward, which is 'set before us of our meriting to live happily in eternity' (Augustine, 2008: 50). In Grace and Free Choice 7.18, Augustine highlighted eternal life as a reward, and that it not a due payment to our merits but a gift of God. Therefore, Letters 194.5.19 presents that God will crown his 'own crown' upon us if he grants us eternal life as a reward for our good works:

What merit, then, does a human being have before grace, so that by that merit he may receive grace, when God crowns our merits, he only crowns his own gift? For, just as we have obtained mercy from the very beginning of faith, not because we were believers but in order that we might be believers, so in the end, when there will be eternal life, he will crown us, as scripture says, in compassion and mercy (Psalm 103:4)... even eternal life itself... is given as recompense for preceding merits... it too is called grace for no other reason than that it is given gratuitously, not because it is not given to our merits but because even the very merits to which it is given were given to us (2004 b: 296).

Here is a theological dilemma. How can eternal life be both a reward for good works and a grace of God? In opposition to antinomians, Augustine needed to highlight that God promised to reward their good works. As a biblical exegete and preacher, Augustine knew that the Bible promised judgment according to deeds and eternal life as a reward. If the abusers of sola fide and declarative justification do not have any good works to merit eternal life, they should not hope for their salvation. Eternal life is a just compensation for their good works in a sense. Christians' good works are their own works not because the good works resulted from themselves by their own power but because God produces good works through 
their free choice (Augustine, 1999: 83-84). God created the universe out of nothing without our commitment. However, God will not grant eternal life to us if we do not want to choose him with our own will.

In opposition to Pelagians, on the other hand, the bishop had to teach the gratuitousness of eternal life in order to keep them from being prideful. In what way should we consider eternal life as a grace of God, not a payment for our works. First, it is not us but God that ultimately produces good works in and through us. In Romans 6:23, Paul pronounces the wages of $\sin$ is death because death is the due reward in return for our merits of sin. Instead of saying that the wages of righteousness is eternal life, however, Paul presents eternal life as the grace of God out of his mercy because it is God, not us, who works in us for good works (Augustine, 1999: 21). Second, we cannot reach perfection on earth because of our sinful flesh although we have been justified and are growing in righteousness. In Revisions 2.33, Augustine (2010: 140) reminds his readers that no Christian could perfectly observe the law on earth to the extent that he or she does not have to pray, 'Forgive us our debts'. Again using Romans 6:23 in Letters 194.5.21, Augustine (2004b: 297) asks his audience to trust in Jesus Christ since he, our mediator, alone could grant eternal life to them. Augustine wants his audience to realize that eternal life is the work of God for us, and our remaining sinfulness, even after our conversion, deserves punishment, not eternal life. Therefore, no one should praise themselves and demand eternal life as if it were his or her due payment from God. In Letters 194.3.6 (2004 b: 291), Augustine explained that the justified should not be boastful about their good works not only because their works were done by the grace of God but also because their works deserve eternal damnation, instead of eternal life. The justified are still in sinfulness even after their justification. Therefore, hell will be a right payment to the merits of the justified if they seek the absolute fair evaluation of God about their lives. The merits of Christians cannot avoid divine condemnation. Augustine does not deny some relative righteousness and merits in the good works of the justified because works are done by those who were made righteous. However, Augustine returns to the centrality of the gratuitousness of grace in the matter of eternal life as a reward.

If we are not going to be perfect even at the end of our lives, how could we receive eternal life as a reward? Explanations of the Psalms 83.16 provides Augustine's answer. Based on God's own promise to reward the good works of his children in spite of the imperfection of their works, God voluntarily presented himself as a debtor not because he received any favor from us but because he promised us about a reward out of his sheer grace (Augustine, 2002: 202). Therefore, we, if not perfect, could ask God to give us what he promised, not what he received from us. Therefore, eternal life cannot be a payment to our merits. As God promised, we, the truly justified, will be rewarded with eternal life for our good works graciously, not proportionately to our meritorious good works. McGrath (2005: 44) summarizes Augustine's position on eternal life as a reward for our merits in the fol- 
lowing: 'While merit before justification is indeed denied, its reality and necessity after justification are equally strongly affirmed. It must be noted, however, that Augustine understands merit as a gift from God to the justified sinner.' Does Augustine present our merits based on good works assisted by cooperative grace as the necessary fruits of or as an inevitable cause of our justification? McGrath does not clarify in what sense our merits are necessary in relation to eternal life.

According to Bucer, Augustine would view our merits as the inevitable evidence of our genuine justification based on imputed righteousness. By repeating Augustine's phrase-God crowns nothing but his own gifts when he crowns our merits-Bucer faithfully follows Augustine's emphasis on the mercy and grace of God in granting eternal life to us. The two theological arguments, 'justification by faith alone apart from good works' and 'salvation as a future reward' are not mutually exclusive in the mind of Bucer. For Bucer God simply decided to grant rewards to those who obeyed his commandments as he promised although their obedience is not perfect. Bucer does not consider Augustine's phrase 'God crowns his own works' as the bishop's theological verification of good works subsequent to faith as meritorious in themselves. According to Bucer (Lugioyo, 2010: 143), the correct reading of Augustine's phrase is that good works 'could only be said to be meritorious based on their relation to being the very works of God within believers'. Are good works necessary for eternal life? Bucer's answer is definitely 'Yes', not because of the worthiness of our merits but because of their role to witness the grace and merit of Christ that we received in justification. Calvin also argued that we do not have to see sola fide in justification and reward according to good works as mutually exclusive to each other if we could understand the promise of the gospel to make not only our persons, but also our works 'acceptable' to God (Calvin, 1960: 806). For Calvin both acceptances are the fruits of the grace of God, not

our worthiness. Since God promised to bless those who observe his law, but if their obedience cannot be perfect, and graciously determined to honor the fruit of the ministry of the Holy Spirit in them, God's reward for our good works cannot be meritorious to us (Calvin, 1960: 805-807). In light of Bucer and Calvin on merit and eternal life, we could say that Augustine's presentation of the relationship between merit and eternal life is not necessarily Catholic but biblical since good works for Augustine are always testimonial, not causative, to justification based on the free grace of God.

\section{Conclusion}

Augustine indeed presented a patristic tradition of sola fide, declarative and imputed righteousness and a necessary theological distinction between justification and sanctification without creating a systematic categorical division that Victorinus and Ambrosiaster had already presented in the fourth-century exegetical tradition of Latin Christianity. Therefore, we should not assume that such Reformational thoughts on justification were not known to Augustine. Augustine discusses justifi- 
cation in the context of regeneration or conversion. Augustine uses the term 'justification' in a twofold way. First, justification refers to the divine forgiveness of our sins through Christ's redemptive work. Christians are legally justified before God by being liberated from the guilt and penalty that they should pay. His teaching on declarative justification in The Spirit and Letter 26.45 is not to be considered as an accidental thought in his doctrine of justification. The metaphor of clothing for justification in Grace and Free Choice 6.13 and The Spirit and the Letter 9.15 also shows the declarative or imputed righteousness of justification. Second, justification also refers to the newness of life or the image of God within believers assisted by the Holy Spirit who helps them participate in the holy God. However, the newness of life in justification is not to be equated with the growth of righteousness in us. Since Augustine sees sin and forgiveness not only in a legal sense but also in an ontological sense, he believes that Christians must have some real righteousness within themselves simultaneously when they are justified. The inherent righteousness of justification refers to the initial sanctification that occurs at the moment of forgiveness. Therefore, justification in the theology of Augustine is not a process but an event.

The divine acceptance of sinners does not depend on the growth of righteousness assisted by cooperative grace. Even the newness of life given to us at the same time of declarative justification cannot be a cause for the divine acceptance. The sole ground of the divine acceptance is declarative or imputed righteousness by faith in justification. Augustine's strong sense of total depravity and pessimism about perfection on earth does not allow him to make justification contingent upon human co-operation with grace although co-operative grace must be always operative within any true believer. Therefore, justification depends on the imputed righteousness that is located in Christ alone, not in us. Concerning the way Augustine preserves the relationship between justification and sanctification, we need to understand the bishop's different theological situation. As we observed, some antinomian abusers of sola fide appealed to the declarative nature of justification, regardless of their intentional desire to remain in sin, as the sole cause of the divine acceptance of sinners. This may be the main reason why Augustine did not speak of the declarative or imputed aspect of justification. Rather, he had to emphasize the indissoluble and simultaneous relationship between justification and sanctification. That may be why Augustine stressed the importance of co-operative grace in the renewal of human nature. In addition, his work in the Pelagian controversy led him to use the same terminologies in a way that he could preserve the same degree of gratuitousness of grace in gradual growth in righteousness as in instantaneous justification. Unlike Catholics, for Augustine, that dual usage of justification - the forgiveness of sins and the beginning of renewal-does not necessitate him to base God's acceptance of sinners on their inner righteousness. As Chemnitz and Calvin complain, on the one hand, we could wish that Augustine would have used the theological terms such as grace, righteousness and justifica- 
tion more distinctively between God's acceptance of sinners and their growth in righteousness. As Bucer defends, on the other hand, we can see his positive evaluation of good works subsequent to conversion and the necessity of co-operative grace in terms of the effect of justification. Augustine could be a forerunner of the Reformational doctrine of justification although his doctrine of justification is not identical with that of the Reformers in every aspect or emphasis. However, we have found a solid theological affinity between Augustine and Bucer in the doctrine of justification.

\section{Bibliography}

Ambrosiaster (1966) Commentarius in epistulas Paulinas. Pars I: In epistulam ad

Romanos. In Vogels, HJ (ed) Corpus Scriptorum Ecclesiasticorum Latinorum, volume 81.1. Salzburg: University of Salzburg.

Ambrosiaster (1969) Commentarius in epistulas Paulinas. Pars III: In epistulas ad Galatas, ad Efesios, ad Fillippenses, ad Colossenses, ad Thessalonicenses, ad Timotheum, ad Titum, ad Filemonem. In Vogels, HJ (ed) Corpus Scriptorum Ecclesiasticorum Latinorum, volume 81.3. Salzburg: University of Salzburg.

Ambrosiaster (2009a) Commentaries on Romans and 1-2 Corinthians. In Oden, TC and Bray, G (eds) Ancient Christian Texts. Downers Grove, IL: InterVarsity Press.

Ambrosiaster, (2009b) Commentaries on Galatians_Philemon. In Oden, TC and Bray, G (eds) Ancient Christian Texts. Downers Grove, IL: InterVarsity Press.

Augustine (1992) Sermons (148-183), III.5 (The Works of Saint Augustine: A Translation for the 21st Century). Hyde Park, NY: New City Press.

Augustine (1997) Answer to the Pelagians, I.23 (The Works of Saint Augustine: A Translation for the 21st Century). Hyde Park, NY: New City Press.

Augustine (1999) Answer to the Pelagians, IV.26 (The Works of Saint Augustine: A Translation for the 21 st Century). Hyde Park, NY: New City Press.

Augustine (2000a) Expositions of the Psalms (1-32), III.15 (The Works of Saint Augustine: A Translation for the 21 st Century). Hyde Park, NY: New City Press.

Augustine (2000b) Expositions of the Psalms (33-50), III.16 (The Works of Saint Augustine: A Translation for the 21 st Century). Hyde Park, NY: New City Press.

Augustine (2002) Expositions of the Psalms (73-98), III.18 (The Works of Saint Augustine: A Translation for the 21 st Century). Hyde Park, NY: New City Press.

Augustine (2004a) Expositions of the Psalms (121-150), III.20 (The Works of Saint Augustine: A Translation for the 21st Century). Hyde Park, NY: New City Press.

Augustine (2004b) Letters (156-210), II.3 (The Works of Saint Augustine: A Translation for the 21 st Century). Hyde Park, NY: New City Press.

Augustine (2008) Responses to Miscellaneous Questions, I.12 (The Works of Saint Augustine: A Translation for the 21st Century). Hyde Park, NY: New City Press. 
Augustine (2009) Homilies on the Gospel of John 1-40, I.12 (The Works of Saint Augustine: A Translation for the 21 st Century). Hyde Park, NY: New City Press.

Augustine (2010) Revisions, I.2 (The Works of Saint Augustine: A Translation for the 21 st Century). Hyde Park, NY: New City Press.

Augustinus (1841) In Joannis evangelium tractatus, XXXV (Patrologiae Cursus Completus, Series Latina). Paris.

Augustinus (1865) De Spiritu et littera liber unus, XLIV (Patrologiae Cursus Completus, Series Latina). Paris.

Augustinus (1887) De Fide et Operibus liber unus, XL (Patrologiae Cursus Completus, Series Latina). Paris.

Augustinus (1956) Enarrationes in psalmos I-L. (Corpus Christianorum. Series Latina) Turnhout: Brepols.

Beeke, JR and Jones, M (2012) A Puritan Theology: Doctrine for Life. Grand Rapids, MI: Reformation Heritage Books.

Buchanan, J (1867) The Doctrine of Justification: An Outline of Its History in the Church. Edinburgh: T\&T Clarke.

Calvin, J (1960) Institutes of the Christian Religion. Philadelphia, PA: Westminster Press.

Calvin, J (2005) Commentaries on the Epistles of Paul to the Galatians and Ephesians. Grand Rapids, MI: Baker Books.

Chemnitz, M (1989) Loci Theologici, volume 2. Saint Louis, MO: Concordia Publishing House.

Cho, D (2012) Ambrosiaster on Justification by Faith Alone in his Commentaries on the Pauline Epistles. Westminster Theological Journal 74(2): 277-290.

Cho, D (2014) Justification in Marius Victorinus' Pauline Commentaries: Sola Fide, Solo Christo, and Sola Gratia Dei. Journal for Baptist Theology and Ministry 11(1): 325.

Eno, RB (1984) Some Patristic Views on the Relationship of Faith and Works in Justification. Recherches augustiniennes 19: 3-27.

Green, BG (2010) Shapers of Christian Orthodoxy: Engaging with Early and Medieval Theologians Downers. Downers Grove, IL: IVP Academic.

Hägglund, B (1966) History of Theology. St. Louis, MO: Concordia Publishing House.

Heckel, M (2004) Is R. C. Sproul Wrong About Martin Luther? An Analysis of R. C. Sproul's Faith Alone: the Evangelical Doctrine of Justification with Respect to Augustine, Luther, Calvin, and Catholic Luther Scholarship. Journal of Evangelical Theological Society 47(1): 89-120.

Hiestand, G (2007) Augustine and the Justification Debates: Appropriating Augustine's Doctrine of Culpability. Trinity Journal 28(1): 115-139.

Lane, ANS (2004) Twofold Righteousness: A Key to the Doctrine of Justification? In Husbans, M and Treier, D (eds) Justification: What's at Stake in the Current Debates. Downers Grove, IL: InterVarsity Press, pp. 205-224.

PERICHORESIS 12.2 (2014) 
Lugioyo, B (2010) Martin Bucer's Doctrine of Justification: Reformation Theology and Early Modern Irenicism. Oxford: Oxford University Press.

Marius Victorinus (1986) In epistulam Pauli ad Ephesios, In epistulam Pauli ad Galatas, In epistulam Pauli ad Philippenses. In Gori, F (ed) Corpus Scriptorum Ecclesiasticorum Latinorum, volume 83.2. Salzburg: University of Salzburg.

Marius Victorinus (2005) Commentary on Galatians. In Cooper, SA (trans), Oxford Early Christian Studies. Oxford: Oxford University Press.

McGrath, AE (2005) Iustitia Dei: A History of the Christian Doctrine of Justification. New York, NY: Cambridge University Press.

Raith II, CD (2001) Calvin's Critique of Merit, and why Aquinas (Mostly) Agrees. Pro Ecclesia 20(2): 152-154.

Rydstrøm-Poulsen, A (2002) The Gracious God: Gratia in Augustine and the Twelfth Century. Copenhagen: Akademisk.

Stephens, WP (1970) The Holy Spirit in the Theology of Martin Bucer. New York, NY: Cambridge University Press.

Saarnivaara, U (1951) Luther Discovers the Gospel: New Light Upon Luther's Way from Medieval Catholicism to Evangelical Faith. Eugene, OR: Wipf and Stock Publishers.

O'Collins, G and Rafferty, O (2011) Roman Catholic View. In Beilby, JK and Eddy, PR (eds) Justification: Five Views. Downers Grove, IL: IVP Academic.

Venema, CP (2007) Accepted and Renewed in Christ: the Twofold Grace of God and the Interpretation of Calvin's Theology (Reformed Historical Theology). Göttingen: Vandenhoeck \& Ruprecht.

Williams, DH (2006) Justification by Faith: A Patristic Doctrine. Journal of Ecclesiastical History 57(4): 649-667.

Wright, D (2006) Justification in Augustine. In McCormack (ed) Justification in Perspective: Historical Developments and Contemporary Challenges. Grand Rapids, MI: Baker Academic, pp. 55-71.

Toon, P (1983) Justification and Sanctification. Wheaton, IL: Crossway Books.

Woodbridge, JD and James III, FA (2013) From Pre-Reformation to the Present Day: The Rise and Growth of the Church in Its Cultural, Intellectual, and Political Context. Church History, volume 2. Grand Rapids, MI: Zondervan. 